\title{
Comparison of Calcium Content between Blossom-End Rot and Healthy Fruits in Red Pepper (Capsicum annuum L.) Grown in Open Field
}

\author{
Seong Eun Lee*, Jin Myeon Park, Jae Seung Noh, and Tae Jun Lim \\ Horticultural \& Herbal Crop Environment Division, National Institute of Horticultural \& \\ Herbal Science, Suwon 441-440, Korea
}

\begin{abstract}
The causes of blossom-end rot (BER) are still not understood cleary, although there was a lot of research on the development of BER over 100 years. This experiment was conducted to investigate the influence of Ca content of fruit on the incidence of BER in red pepper. BER affected fruits and healthy fruits had been harvested and the samples were divided into two parts, the upper and the lower, for chemical analysis to determine the content of mineral nutrients in the tissue. The content of nitrogen $(N)$, phosphorus $(P)$, potassium (K) and magnesium (Mg) was higher in the BER affected fruits and the difference of each nutrient content was revealed much larger in the lower part of the fruit but there were no significant differences in calcium content between the BER and the healthy fruits of red pepper, in this experiment. The results indicate that it is difficult to find a certain relation between the calcium content of the fruit and the occurrence of blossom-end rot.
\end{abstract}

Key words: Capsicum annuum, physiological disorder, blossom-end rot, calcium deficiency

\section{Introduction}

Blossom-end rot is generally attributed to an inadequacy of calcium in the fruits and it is often called a 'Ca-related disorder' (Shear, 1975). According to Adams and Ho (1993), the BER is usually the result of reduced calcium uptake by the roots, due to restricted water supply or interactions with other nutrients such as $\mathrm{NH}_{4}-\mathrm{N}$ in the root zone (Adams and Ho, 1995). However several authors could not find significant differences in $\mathrm{Ca}$ content of tissues between the BER affected fruit and healthy fruit from affected or non-affected plants, respectively (Barker and Ready, 1994; Franco et al., 1999; Murray et al., 1972; Saure, 2001; Spurr, 1959). Recently, Freitas et al. (2011) stated that Ca deficiency disorders such as BER in tomato (Solanum lycopersicum) fruit may be induced by abnormal regulation of $\mathrm{Ca}$ partitioning and distribution in the cell. The purpose of this study is to investigate whether there is a certain relation between the amount of calcium in the fruit tissue of red pepper and the occurrence of blossom-end rot.

\footnotetext{
Received : January 11. 2012 Accepted : February 6. 2012

*Corresponding author : Phone: +82312906225

E-mail: pplm96@korea.kr
}

\section{Materials and Methods}

Plant growth and sample preparation Red pepper (Capsicum annuum cv. Geumtap) seeds had been sown on march 7th and the seedlings were transplanted in an open field from plug trays on may 16th. Red pepper fruits were harvested on August 2nd and the samples containing both BER affected fruits and healthy fruits were randomly selected for chemical analysis of mineral content, respectively. Red peppers were divided into two parts, the upper and the lower. Then the samples were dried at $70^{\circ} \mathrm{C}$ in a drying oven after removing the seeds and placenta of the fruit. Finally the samples were finely ground by using a blender.

Plant analysis Chemical analysis for determination of the mineral content of each sample was conducted according to Methods of soil chemical analysis (NIAST, 2000). Quantitative analysis of plant nitrogen followed Kjeldahl method. About $3 \mathrm{~g}$ catalyst mixture $\left(\mathrm{K}_{2} \mathrm{SO}_{4}\right.$ $: \mathrm{CuSO}_{4}=9: 1$ ) and $10 \mathrm{~mL}$ concentrated sulfuric acid were added to $0.50 \mathrm{~g}$ of dry plant samples for digestion, and then the distillate obtained by Kjeldahl apparatus (Kjeltec 8400, Foss, Sweden) was titrated with stand- 
Table 1. The mineral content of red pepper fruit grown in open field.

\begin{tabular}{|c|c|c|c|c|c|c|c|}
\hline \multicolumn{3}{|c|}{ Sort } & $\mathrm{N}$ & $\mathrm{P}$ & $\mathrm{K}$ & $\mathrm{Ca}$ & $\mathrm{Mg}$ \\
\hline & & & ------ & ---- & $\mathrm{g} \mathrm{kg}^{-1}$ & 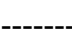 & ------ \\
\hline \multirow{4}{*}{2011} & \multirow{2}{*}{ U.P. ${ }^{\dagger}$} & $\mathrm{BER}^{\S}(\mathrm{A})$ & 28.9 & 5.06 & 31.3 & 0.89 & 2.12 \\
\hline & & H.F. ${ }^{\mathbb{P}}(\mathrm{B})$ & 22.9 & 3.37 & 28.8 & 0.60 & 1.65 \\
\hline & \multirow{2}{*}{ L.P. ${ }^{\ddagger}$} & BER (C) & 35.1 & 4.97 & 33.7 & 1.66 & 2.91 \\
\hline & & H.F. (D) & 21.2 & 2.59 & 34.8 & 0.57 & 1.35 \\
\hline \multirow{4}{*}{2010} & \multirow{2}{*}{ U.P. } & BER (E) & 26.9 & 3.73 & 42.3 & 1.02 & 1.57 \\
\hline & & H.F. (F) & 20.9 & 3.14 & 34.4 & 0.95 & 1.27 \\
\hline & \multirow{2}{*}{ L.P. } & $\operatorname{BER}(G)$ & 26.9 & 3.75 & 40.1 & 0.79 & 1.56 \\
\hline & & H.F. (H) & 21.0 & 3.28 & 33.2 & 0.75 & 1.27 \\
\hline \multirow{4}{*}{2009} & \multirow{2}{*}{ U.P. } & BER (I) & 27.7 & 4.48 & 27.0 & 0.93 & 1.68 \\
\hline & & H.F. (J) & 26.5 & 4.25 & 26.6 & 1.08 & 1.71 \\
\hline & \multirow{2}{*}{ L.P. } & BER (K) & 31.6 & 4.69 & 29.0 & 0.57 & 1.78 \\
\hline & & H.F. (L) & 26.7 & 3.77 & 31.2 & 0.63 & 1.32 \\
\hline \multirow{6}{*}{\multicolumn{2}{|c|}{ Significance (t-test) }} & $A \times B$ & $*$ & $* *$ & NS & $* *$ & $* *$ \\
\hline & & $C \times D$ & $* *$ & $* *$ & NS & $* *$ & $* *$ \\
\hline & & $E \times F$ & $* *$ & $* *$ & $* *$ & NS & $*$ \\
\hline & & $\mathrm{G} \times \mathrm{H}$ & $* *$ & $*$ & $* *$ & NS & $*$ \\
\hline & & $\mathrm{I} \times \mathrm{J}$ & NS & NS & NS & $\mathrm{NS}$ & NS \\
\hline & & $\mathrm{K} \times \mathrm{L}$ & $* *$ & $* *$ & $*$ & NS & $* *$ \\
\hline
\end{tabular}

${ }^{\dagger}$ U.P., Upper part of red pepper fruit; ${ }^{\ddagger}$ L.P., Lower part of red pepper fruit; ${ }^{\S}$ BER, Blossom-end rot affected fruit; ${ }^{\mathbb{P}}$ H.F., Healthy (non-affected) fruit.

ardized $0.1 \mathrm{~N} \mathrm{HCl}$. Total $\mathrm{P}$ content in each plant sample was measured by the procedure of ammonium vanadate method and determined by reading the absorbance at $410 \mathrm{~nm}$ wavelength by colorimetry using UV/VIS spectrophotometer (Cintra 6, GBC, Australia). The cation $(\mathrm{K}, \mathrm{Ca}$ and $\mathrm{Mg})$ content in each part of red pepper fruit was measured by ICP (SDS-720, GBC, Australia) after the digestion of plant samples by adding $10 \mathrm{~mL}$ 85:15 nitric-perchloric acid mixture $\left(\mathrm{HNO}_{3}-\mathrm{HClO}_{4}\right)$ and the pyrolysis of intermediate substances obtained from the digestion process.

\section{Results and Discussion}

Accumulated result of chemical analysis repeated for 3 years on the mineral content of red pepper fruit cultured in open field shows that the content of $\mathrm{N}$, $\mathrm{P}, \mathrm{K}$ and $\mathrm{Mg}$ is higher in the BER affected fruit than the healthy fruit and the gap was revealed much larger in the lower part than the upper part of the fruit. But there were no significant differences in calcium content between the BER and the healthy fruits and even the BER affected fruits had more calcium in their tissue (Table 1). This result was coincident with the previous reports (Barker and Ready, 1994; Franco et al., 1999; Murray et al., 1972; Saure, 2001; Spurr, 1959), which emphasize that there are no significant differences in Ca content of tissues between the BER affected fruit and the healthy fruit from affected or non-affected plants, respectively. It means that it is difficult to find a certain relation between the calcium content of the fruit and the occurrence of blossom-end rot.

\section{Conclusion}

In this experiment continued for 3 years, we confirmed that there are no significant differences in calcium content between the BER and the healthy fruits of red pepper. It is suggested that additional research on the exact cause of blossom-end rot is needed in the future. 


\section{References}

Adams, P. and L.C. Ho. 1993. Effects of environment on the uptake and distribution of calcium in tomato and on the incidence of blossom-end rot. Plant Soil 154:127-132.

Adams, P. and L.C. Ho. 1995. Uptake and distribution of nutrients in relation to tomato fruit quality. Acta Hort. 412:374-387.

Barker, A.V. and K.M. Ready. 1994. Ethylene evolution by tomatoes stressed by ammonium nutrition. J. Am. Soc. Hort. Sci. 119:706-710.

Franco, J.A., P.J. Perez-Saura, J.A. Fernandez, M. Parra, and A.L. Garcia. 1999. Effect of two irrigation rates on yield, incidence of blossom-end rot, mineral content and free amino acid levels in tomato cultivated under drip irrigation using saline water. J. Hort. Sci. Biotechnol. 74:430-435.

Freitas, S.T., M. Padda, Q. Wu, S.H. Park, and E.J. Mitcha.
2011. Dynamic Alternations in Cellular and Molecular Components during Blossom-End Rot Development in Tomatoes Expressing sCAX1, a Constitutively Active $\mathrm{Ca}^{2+} / \mathrm{H}^{+}$ Antiporter from Arabidopsis. Plant Physiol. 156:844-855.

Murray, S.A., A.R. Spurr, and K.N. Paulson. 1972. Electron probe analysis of $\mathrm{Ca}, \mathrm{Mg}$, and $\mathrm{K}$ in the fruit of the tomato, Lycopersicon esculentum, with reference to blossom-end rot. Agron. J. 64:586-588.

NIAST. 2000. Methods of soil chemical analysis. National Institute of Agricultural Science and Technology, RDA, Suwon, Korea.

Saure, M.C. 2001. Blossom-end rot of tomato (Lycopersicon esculentum Mill.) : a calcium- or a stress-related disorder? Sci Hortic. 90:193-208.

Shear, C.B. 1975. Calcium related disorders of fruits and vegetables. HortScience 10:361-365.

Spurr, A.R. 1959. Anatomical aspects of blossom-end rot in the tomato with special reference to calcium nutrition. Hilgardia 28:269-295. 